\title{
Seasonal changes in fish assemblages in the River Minho tidal freshwater wetlands, NW of the Iberian Peninsula
}

\author{
Micaela Mota ${ }^{1 *}$, Ronaldo Sousa ${ }^{1,2}$, Ana Bio $^{1}$, Jorge Araújo $^{1}$, Catarina Braga ${ }^{1}$ \\ and Carlos Antunes ${ }^{1,3,4}$ \\ ${ }^{1}$ Interdisciplinary Centre of Marine and Environmental Research (CIIMAR/CIMAR), University of Porto, Rua dos Bragas 289, \\ P 4050-123 Porto, Portugal \\ 2 CBMA - Centre of Molecular and Environmental Biology, Department of Biology, University of Minho, Campus de Gualtar, \\ 4710-057 Braga, Portugal \\ 3 Aquamuseu do Rio Minho, Parque do Castelinho, 4920-290 Vila Nova de Cerveira, Portugal \\ ${ }^{4}$ ESG - Gallaecia University School, Largo das Oliveiras, 4920-275 Vila Nova de Cerveira, Portugal
}

Received 14 August 2013; Accepted 9 April 2014

\begin{abstract}
The ichthyofauna of the River Minho tidal freshwater wetlands (TFWs) was studied in a semienclosed area, between June 2007 and May 2010, to determine temporal patterns of abundance, biomass and species composition. Fish catches, standardized by the number of fyke nets and by the fishing effort, were analysed and related to river flow, water temperature and precipitation. In total, 21 fish species were identified including six non-indigenous species (NIS) which represented $15 \%$ of the total captures (yet $43 \%$ of the biomass). Regarding ecological guilds, $82 \%$ were freshwater species $(61 \%$ of the biomass) which included all NIS, whereas $13 \%$ of the catches were catadromous species (31\% biomass) corresponding to eels. Only $4 \%$ were estuarine species (1\% biomass) and together marine estuarine opportunists and anadromous species accomplished 1\% (2 and 6\% biomass, respectively). The fish assemblage showed seasonal patterns with a clear distinction between autumn/winter and spring/summer periods. Significant differences in abundance and biomass were also detected between autumn/winter of 2007/2008 and 2008/2009, i.e., inter-annual variations, with the latter period with lower catches yet higher dominance of NIS. Besides, higher water temperature had a significant negative effect on the observed number of species, but a positive effect on the abundance and biomass of NIS. More attention has to be given to TFWs and their role in structuring fish assemblages, because this information is vital for a sound management, conservation and restoration of estuarine areas.
\end{abstract}

Key words: abiotic factors / assemblage / ichthyofauna / Minho estuary / non-indigenous species

\section{Introduction}

Estuaries are well-recognized areas of high productivity that support a diversity of species, being also responsible for important ecological functions and services (Little, 2000; Vasconcelos et al., 2007). However, they have been subjected to a great variety of human impacts (e.g., pollution, overexploitation, loss of habitat and climate change), which have caused depletion of numerous formerly important species, destroyed or fragmented important estuarine habitats, such as seagrasses, oyster reefs and marshes, degraded water quality and introduced several non-indigenous species (NIS) (Kappel, 2005; Lotze et al., 2006).

\footnotetext{
*Corresponding author: mmota@ciimar.up.pt
}

In recent years, there have been numerous studies on estuarine areas, addressing a multitude of ecological subdisciplines and focusing on a great variety of organisms (Attrill, 2002; Attrill and Rundle, 2002; Sousa et al., 2008a). Most of these studies focused on the lower estuarine areas, subjected to brackish water conditions, almost ignoring those upstream estuarine areas that still continue to be influenced by tides but are subjected to freshwater conditions. These tidal freshwater wetlands (TFWs) constitute a particular estuarine habitat where characteristic plant and animal species occur, reflecting the unique biological, chemical and physical conditions. Productivity of TFWs is similar to that of salt marshes but plant and macrofaunal diversity are higher. Additionally, TFWs provide areas with low tidal influence and essential passages for commercially and conservationally important 


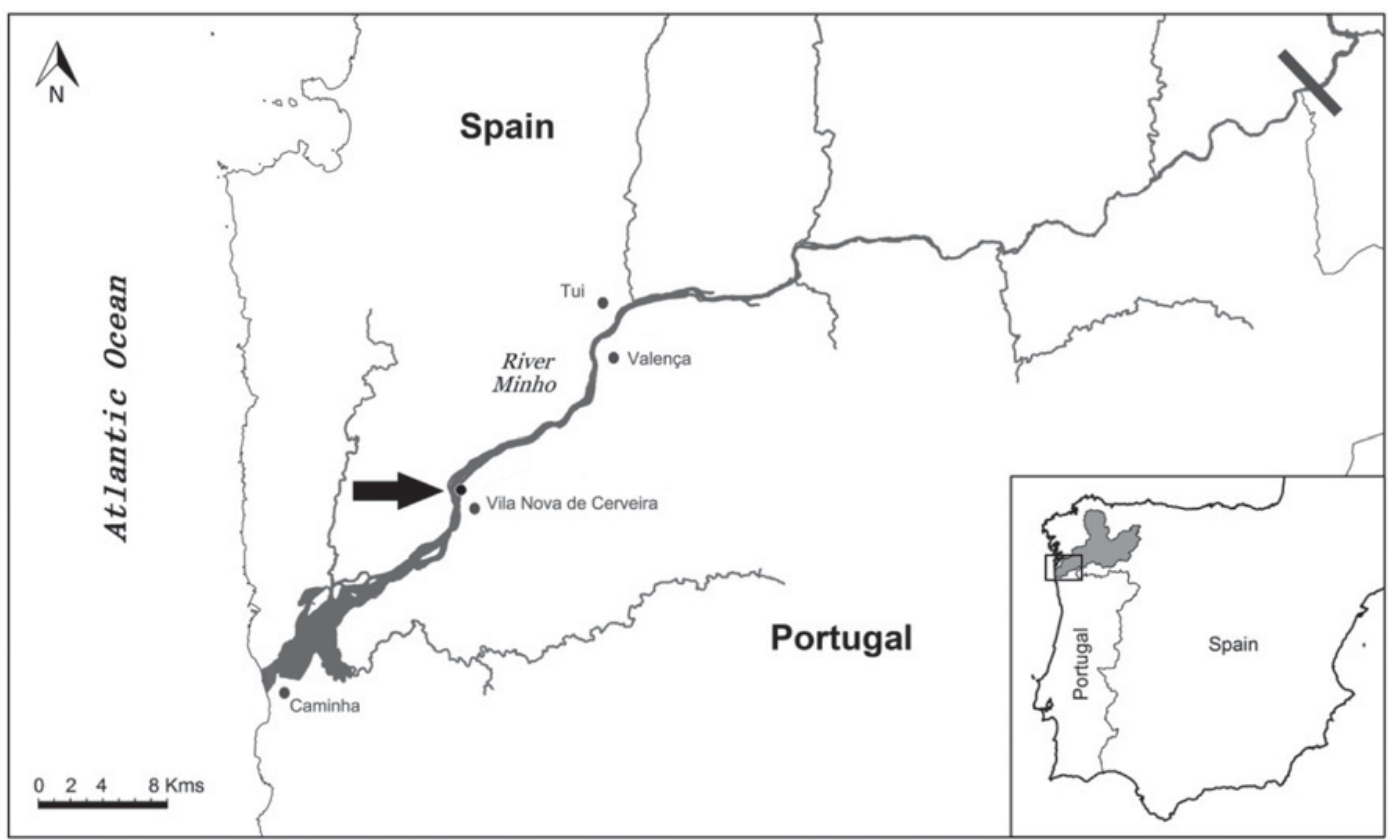

Fig. 1. Map of the River Minho estuary (Caminha-Valença) and the study area showing the TFW semi-enclosed sampling location (arrow).

migratory fish species and offer nursery conditions or refuges from predators for juvenile fish, molluscs and crustaceans, provide essential feeding and drinking grounds for birds and constitute ideal habitats for numerous other vertebrate and invertebrate species (Sousa et al., 2008a; Barendregt et al., 2009; Kraus and Jones, 2012).

One of the most important faunal groups colonizing estuaries is fishes. In the particular case of TFWs, these areas may be colonized by estuarine and marine species with physiological capacities to tolerate changes in salinity, migratory fish species use TFWs as a passage to upstream areas, and true freshwater species that usually colonize upstream estuarine areas (Schuchardt et al., 1993; Roegner et al., 2010). Despite the ecological importance of fish species colonizing TFWs, there are still few data and little knowledge about the major factors driving spatial and temporal fluctuations in their abundance, biomass and species composition, and the contribution of these TFWs to the ichthyofauna of the whole estuary or basin. Recognizing this gap in knowledge and considering that TFWs have suffered water and habitat degradation, enhanced understanding of the factors that influence species distribution are needed. In theory, this information will then assist better management, restoration or protection of natural resources and ecosystems (Buisson et al., 2008).

Therefore, the aim of this study was to increase the existing knowledge about the ichthyofauna from Iberian estuarine TFWs, using the River Minho as a case study. In recent years, several studies have investigated the fauna of the Minho estuary, namely macroinvertebrates (Sousa et al., 2008b), epibenthos (Costa-Dias et al., 2010) and fishes (Antunes and Rodrigues, 2004). However, these studies were mostly focused on the lower estuary, and those regarding fish species were centred on few species (mostly related with professional fishing) and have not considered temporal changes; thus River Minho TFWs are currently poorly known. The temporal (seasonal and inter-annual) variation of fish species was analysed, with species classified according to their origin (endemic, native or non-indigenous), and their ecological and feeding guilds. Observations were further related to water temperature, river flow and precipitation, as potentially relevant environmental factors structuring the fish assemblage.

\section{Materials and methods}

\section{Study area}

The River Minho is an international water body. The last $77 \mathrm{~km}$, from its total length of approximately $300 \mathrm{~km}$, are part of the northwestern boundary between Portugal and Spain (Fig. 1). Its drainage basin covers $17080 \mathrm{~km}^{2}$, and drains to the Atlantic Ocean. The Minho estuary, located on the northwest coast of the Iberian Peninsula (IP), has a total area of $23 \mathrm{~km}^{2}$, a length of about $40 \mathrm{~km}$ and a maximum width of just over $2 \mathrm{~km}$ near the mouth. It is a mesotidal estuary with a mean tidal range of $2 \mathrm{~m}$. Salt intrusion extends on average $11.3 \mathrm{~km}$ and up to $16.8 \mathrm{~km}$ inland during higher spring tides (September). Water movements are highly dynamic and the direction of river water flow is strongly dependent on the freshwater volume.

Rainfall in the River Minho basin exhibits strong seasonal and inter-annual variability which is also 


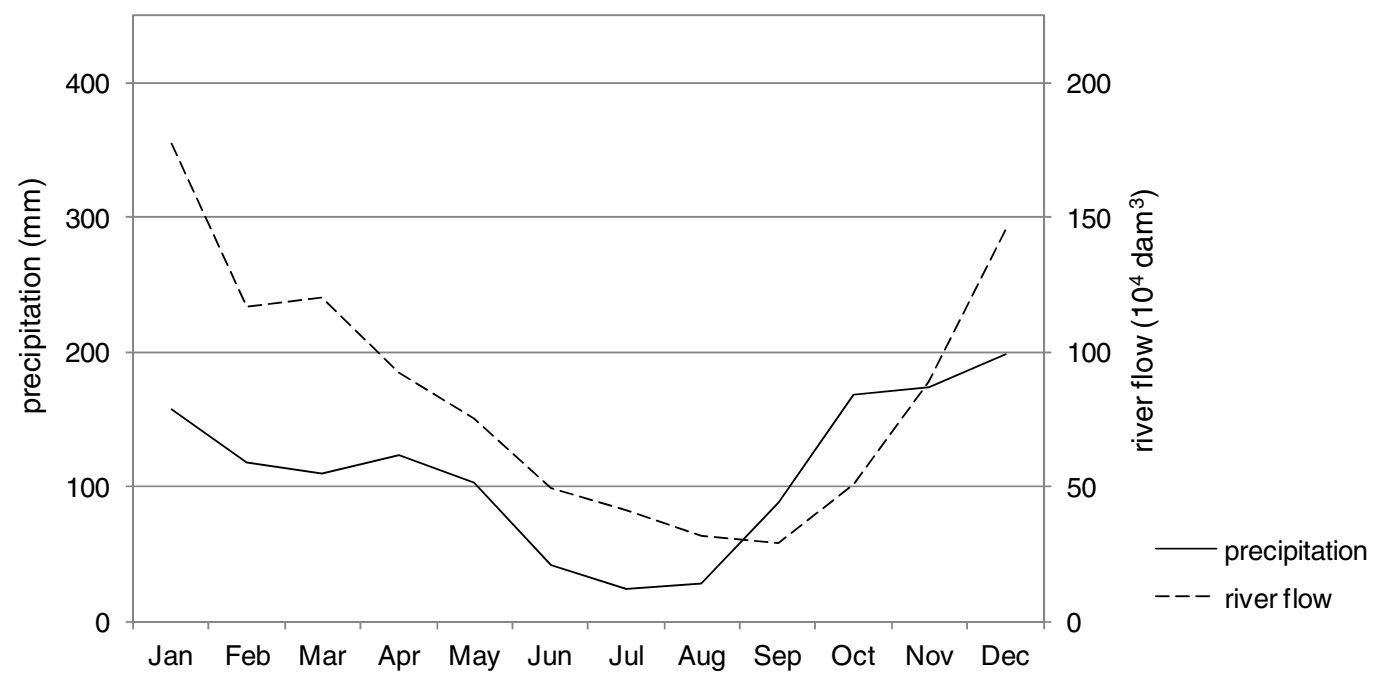

Fig. 2. Two-decades (1990-2009) discharges and precipitation patterns of the River Minho.

reflected in high variability in the discharge regime (Fig. 2). River flow increases usually in autumn or early winter, with a gradual decline during late spring and summer, a typical pattern for Iberian rivers. The annual mean freshwater flow is $300 \mathrm{~m}^{3} \cdot \mathrm{s}^{-1}$ (Ferreira et al., 2003).

The study was conducted in a relatively shallow (depths ranging from 1.5 to $3.0 \mathrm{~m}$ ), semi-enclosed area located $14 \mathrm{~km}$ upstream from the mouth of the river (Fig. 1) that suffers slight saline influence $(<1)$, especially during higher spring tides in the summer/early autumn. This area covers approximately $0.05 \mathrm{~km}^{2}$ and it is greatly heterogeneous, with parts covered with submerged vegetation, parts with fine sediments and others with clean sands. This heterogeneity at a small scale makes this semi-enclosed area particularly suitable for the study of temporal changes in abundance, biomass and diversity of fish species.

\section{Sampling strategy}

From June 2007 to May 2010, fyke nets were used to capture fish. These nets have been successfully deployed in many river conditions, capturing juveniles and adults of the large-bodied species and most of the smaller-bodied species (Humphries et al., 2008; Sousa et al., 2013). The fyke nets $(10 \mathrm{~mm}$ mesh size, $0.7 \mathrm{~m}$ mouth diameter and $7 \mathrm{~m}$ long, $3.5 \mathrm{~m}$ central wing) were placed facing downstream, inside the semi-enclosed area and trying to cover maximum habitat heterogeneity (i.e., sites with submerged vegetation, without submerged vegetation and with fine, medium and coarse sediments). The content of at least three fyke nets (the content of five fyke nets was collected in approximately $65 \%$ of deployments) was collected and conserved in a $40 \mathrm{~L}$ portable tank which was previously filled with water. The empty nets were placed again in the water after content removal until next collection. Samplings took place in a weekly basis $(7.8 \pm 0.4$ days between samplings, mean $\pm \mathrm{SE}, n=141$ ). Fish total weight was measured in situ to the nearest $1 \mathrm{~g}$ using a digital Kern $440-53 \mathrm{~N}$ (maximum $6000 \mathrm{~g}$ ) scale or to the nearest $0.01 \mathrm{~g}$ using a digital Sartorius (maximum $420 \mathrm{~g}$ ) scale, depending on the fish size. Every fish was identified to the species level.

Water temperature and salinity were measured every time the fyke nets content were collected (see above), using a multiparametrical sea gauge YSI 6820.

Discharge data for the Minho River were supplied by the Confederación Hidrográfica del Miño-Sil (Ministerio de Medio Ambiente y Medio Rural y Marino - Spain Government), concerning the Frieira dam discharge and are presented in cubic decameters $\left(\mathrm{dam}^{3}\right)$.

Precipitation data were obtained from the available internet data set of the Monte Aloia (Galicia, Spain) meteorological station.

\section{Data analysis}

Temporal variation was assessed in terms of abundance, biomass, diversity and richness, distinguishing endemic, native and NIS.

Each fish species was assigned to one of the following ecological guilds (adapted from Thiel and Potter, 2001): marine stragglers (MS; species that are typically found irregularly and in small numbers in estuaries and usually in areas of high salinity); marine estuarine opportunists (MO; species that are often abundant in estuaries particularly as juveniles); marine opportunistic residents (OR, species that are often abundant in estuaries but that can also reach and spend relative long periods in freshwater); estuarine species (ES; species which can complete the whole life cycle in estuaries); diadromous species, being either catadromous (CA; species which spawn at sea and feed mainly in freshwater) or anadromous (AN; species which spawn in fresh water and feed mainly in marine 

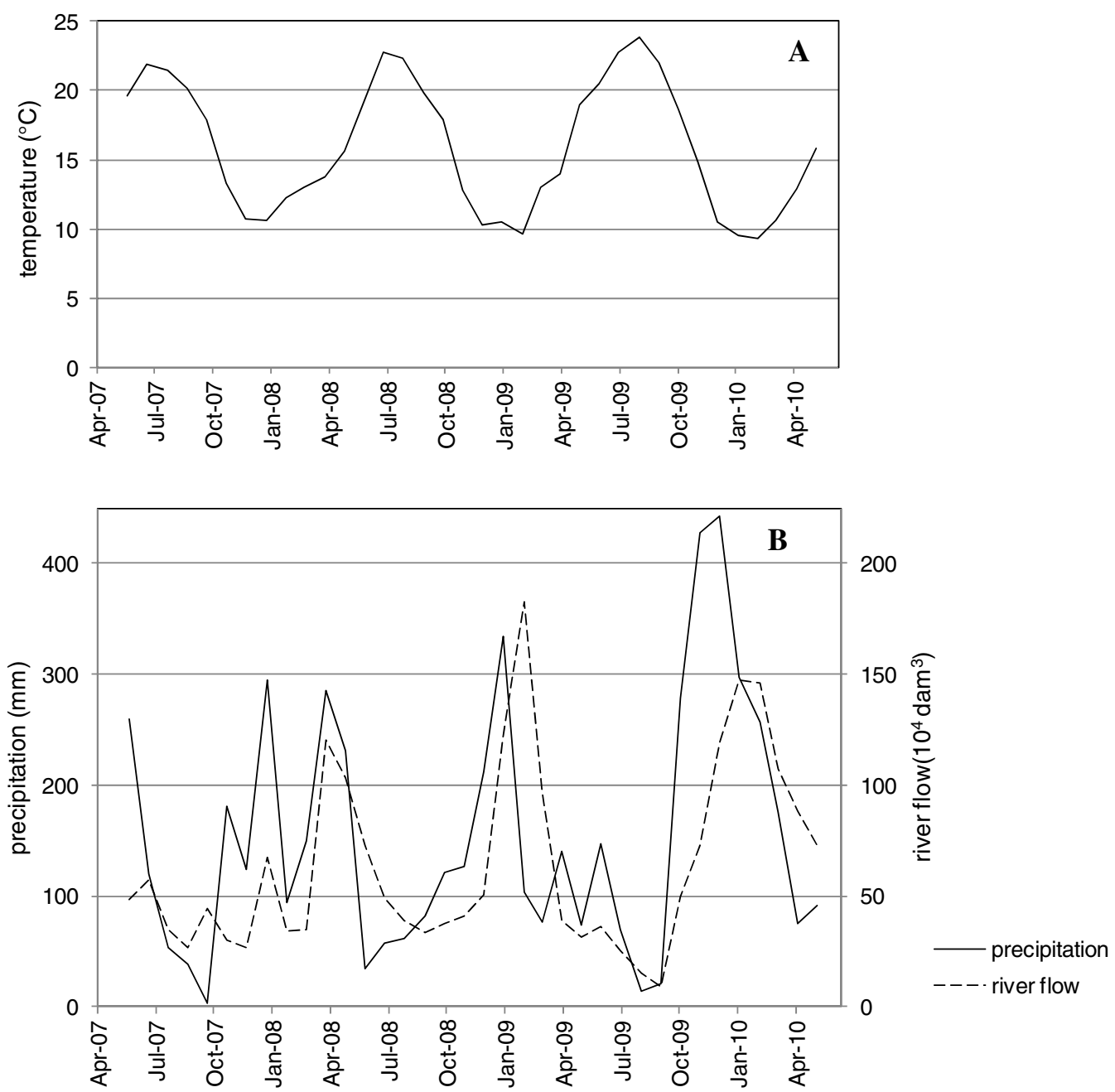

Fig. 3. Water temperatures measured at the TFW (A) and the River Minho discharge from Frieira dam and precipitation measured at Monte Aloia (Galicia, Spain) (B).

waters), and freshwater species (FW; which are typically limited to rivers, but occasionally can enter estuaries during heavy freshwater flooding or are able to inhabit the TFWs).

Food preferences of each species were classified in nine feeding guilds adapted from Elliott and Dewailly (1995) and Elliott and Hemingway (2002). Guilds include species feeding on plankton $(\mathrm{P})$, invertebrates (I), plants (V), invertebrates and fishes (IF), or detritus (D); parasitic species (PS; i.e., feeding on other fish); carnivorous species (CS); species that are partly herbivorous, partly carnivorous but not omnivorous (HC); and omnivorous species (OV).

Analyses were based on monthly mean fish abundance and biomass, with fish catches standardized by dividing fish abundance and biomass by the number of fyke nets and number of days fishing (ind per fyke-net per day and g per fyke-net per day). Univariate analyses include also Shannon-Wiener $\left(\mathrm{H}^{\prime}\right)$ and Pielou's evenness $\left(\mathrm{J}^{\prime}\right)$ indices using the PRIMER v5 package (Clarke and Warwick, 2001). The overall comparisons of variables (abundance, biomass, type and ecological guild, equitability, diversity, water temperature, precipitation and river flow) between years were performed with the STATISTICA v12 (Statsoft Inc.) software using the non-parametric Kruskal-Wallis comparison of mean ranks of groups. Possible effects of temperature, river flow or precipitation on fish abundance and biomass, type of fish and ecological guilds were analysed with simple linear regressions. Multivariate analyses were used to study variations in the fish assemblage. Non-metric Multidimensional Scaling (NMDS), based on Bray Curtis distances, was applied to log-transformed monthly mean abundance (Field et al., 1982). These data were subsequently plotted to show fish species distribution in the ordination space. They were further analysed with hierarchical agglomerative clustering, using Ward's minimum variance method (Ward, 1963; Becker et al., 1988). An analysis of similarity (ANOSIM) was applied to the groups defined by the Cluster analysis, and the similarities percentages procedure (SIMPER) was used to assess the species contributing most to similarity within groups with PRIMER v5 package (Clarke and Warwick, 2001). Other analyses were performed in $\mathrm{R}$ (R Development Core Team, 2009; Oksanen et al., 2010). 
Table 1. List of species catalogued for the Minho estuary (Antunes and Rodrigues, 2004; Costa-Dias et al., 2010) and their presence in different estuarine habitats.

\begin{tabular}{|c|c|c|c|c|c|}
\hline \multirow[b]{2}{*}{ Scientific name } & \multirow[b]{2}{*}{ Type } & \multirow[b]{2}{*}{ Ecological guild } & \multirow[b]{2}{*}{ Feeding guild } & \multicolumn{2}{|c|}{ Presence } \\
\hline & & & & Lower estuary & TFWs \\
\hline \multicolumn{6}{|l|}{ Family Ammodytidae } \\
\hline Ammodytes tobianus & $\mathrm{N}$ & MS & $\mathrm{P}$ & $\mathrm{X}$ & \\
\hline \multicolumn{6}{|l|}{ Family Anguillidae } \\
\hline Anguilla anguilla & $\mathrm{N}$ & CA & IF & $\mathrm{X}$ & $\mathrm{X}$ \\
\hline \multicolumn{6}{|l|}{ Family Atherinidae } \\
\hline Atherina boyeri & $\mathrm{N}$ & ES & $\mathrm{I}, \mathrm{P}$ & $\mathrm{X}$ & $\mathrm{X}$ \\
\hline \multicolumn{6}{|l|}{ Family Balistidae } \\
\hline Pseudobalistes flavimarginatus & $\mathrm{N}$ & MS & I & $\mathrm{X}$ & \\
\hline \multicolumn{6}{|l|}{ Family Belonidae } \\
\hline Belone belone & $\mathrm{N}$ & MS & IF & $\mathrm{X}$ & \\
\hline \multicolumn{6}{|l|}{ Family Bothidae } \\
\hline Arnoglossus laterna & $\mathrm{N}$ & MS & IF & $\mathrm{X}$ & \\
\hline \multicolumn{6}{|l|}{ Family Callionymidae } \\
\hline Callionymus lyra & $\mathrm{N}$ & MS & I & $\mathrm{X}$ & \\
\hline \multicolumn{6}{|l|}{ Family Carangidae } \\
\hline Trachurus trachurus & $\mathrm{N}$ & MS & IF & $\mathrm{X}$ & \\
\hline \multicolumn{6}{|l|}{ Family Centrarchidae } \\
\hline Lepomis gibbosus ${ }^{\mathrm{a}}$ & NIS & FW & $\mathrm{I}, \mathrm{P}$ & & $\mathrm{X}$ \\
\hline Micropterus salmoides & NIS & FW & $\mathrm{CS}, \mathrm{I}$ & & $\mathrm{X}$ \\
\hline \multicolumn{6}{|l|}{ Family Clupeidae } \\
\hline Alosa alosa & $\mathrm{N}$ & $\mathrm{AN}$ & $\mathrm{P}$ & $\mathrm{X}$ & $X^{b}$ \\
\hline Alosa fallax & $\mathrm{N}$ & $\mathrm{AN}$ & $\mathrm{P}$ & $X$ & $\mathrm{X}^{\mathrm{b}}$ \\
\hline Sardina pilchardus & $\mathrm{N}$ & MS & $\mathrm{P}$ & $\mathrm{X}$ & \\
\hline \multicolumn{6}{|l|}{ Family Cobitidae } \\
\hline Cobitis paludica & $\mathrm{N}$ & FW & $\mathrm{I}, \mathrm{V}$ & & $\mathrm{X}$ \\
\hline Family Cyprinidae & & & & & \\
\hline Achondrostoma arcasii & $\mathrm{E}$ & FW & $\mathrm{I}, \mathrm{P}$ & & $\mathrm{X}$ \\
\hline Carassius auratus & NIS & FW & $\mathrm{HC}$ & & $\mathrm{X}$ \\
\hline Cyprinus carpio & NIS & FW & $\mathrm{OV}$ & & $\mathrm{X}$ \\
\hline Gobio lozanoi & NIS & FW & I & & $\mathrm{X}$ \\
\hline Pseudochondrostoma duriense & $\mathrm{E}$ & FW & $\mathrm{I}, \mathrm{V}$ & & $\mathrm{X}$ \\
\hline Squalius carolitertii & $\mathrm{E}$ & FW & $\mathrm{CS}$ & & $\mathrm{X}$ \\
\hline Tinca tinca & NIS & FW & $\mathrm{OV}$ & & $\mathrm{X}$ \\
\hline Family Gasterosteidae & & & & & \\
\hline Gasterosteus gymnurus & $\mathrm{N}$ & FW & I & $\mathrm{X}$ & $\mathrm{X}$ \\
\hline Family Gobiidae & & & & & \\
\hline Aphia minuta & $\mathrm{N}$ & MS & $\mathrm{I}, \mathrm{P}$ & $\mathrm{X}$ & \\
\hline Gobius niger & $\mathrm{N}$ & MS & $\mathrm{I}, \mathrm{P}$ & $\mathrm{X}$ & \\
\hline Pomatoschistus lozanoi & $\mathrm{N}$ & MS & $\mathrm{I}, \mathrm{P}$ & $X$ & \\
\hline Pomatoschistus microps & $\mathrm{N}$ & ES & $\mathrm{I}, \mathrm{P}$ & $X$ & \\
\hline Pomatoschistus minutus & $\mathrm{N}$ & MO & $\mathrm{I}, \mathrm{P}$ & $\mathrm{X}$ & \\
\hline Pomatoschistus pictus & $\mathrm{N}$ & MS & $\mathrm{I}, \mathrm{P}$ & $X$ & \\
\hline Family Lotidae & & & & & \\
\hline Ciliata mustela & $\mathrm{N}$ & MO & IF & $\mathrm{X}$ & \\
\hline Family Moronidae & & & & & \\
\hline Dicentrarchus labrax & $\mathrm{N}$ & MO & IF & $\mathrm{X}$ & $\mathrm{X}$ \\
\hline Dicentrarchus puntactus & & & & & \\
\hline Family Mugilidae & $\mathrm{N}$ & MS & IF & $\mathrm{X}$ & \\
\hline Chelon labrosus & $\mathrm{N}$ & MO & $\mathrm{I}, \mathrm{D}, \mathrm{V}$ & $\mathrm{X}$ & $\mathrm{X}^{\mathrm{b}}$ \\
\hline Liza aurata & $\mathrm{N}$ & MO & $\mathrm{P}, \mathrm{V}$ & $\mathrm{X}$ & $\mathrm{X}$ \\
\hline Liza ramada & $\mathrm{N}$ & OR & $\mathrm{D}, \mathrm{P}, \mathrm{V}$ & $\mathrm{X}$ & $\mathrm{X}$ \\
\hline Mugil cephalus & $\mathrm{N}$ & $\mathrm{MO}$ & $\mathrm{P}, \mathrm{V}$ & $\mathrm{X}$ & $\mathrm{X}$ \\
\hline Family Petromyzontidae & & & & & \\
\hline Petromyzon marinus & $\mathrm{N}$ & $\mathrm{AN}$ & Ps & $\mathrm{X}$ & $\mathrm{X}$ \\
\hline Family Pleuronectidae & & & & & \\
\hline Platichthys flesus & $\mathrm{N}$ & OR & I & $\mathrm{X}$ & $\mathrm{X}$ \\
\hline Family Poeciliidae & & & & & \\
\hline Gambusia holbrooki & NIS & ES & $\mathrm{I}, \mathrm{D}, \mathrm{P}$ & $\mathrm{X}$ & $\mathrm{X}^{\mathrm{b}}$ \\
\hline
\end{tabular}


Table 1. (Contd)

\begin{tabular}{|c|c|c|c|c|c|}
\hline \multirow[b]{2}{*}{ Scientific name } & \multirow[b]{2}{*}{ Type } & \multirow[b]{2}{*}{ Ecological guild } & \multirow[b]{2}{*}{ Feeding guild } & \multicolumn{2}{|c|}{ Presence } \\
\hline & & & & Lower estuary & TFWs \\
\hline \multicolumn{6}{|l|}{ Family Salmonidae } \\
\hline Salmo salar & $\mathrm{N}$ & $\mathrm{AN}$ & $\mathrm{CS}$ & $X$ & $\mathrm{X}^{\mathrm{b}}$ \\
\hline Salmo trutta fario & $\mathrm{N}$ & FW & $\mathrm{IF}$ & & $\mathrm{X}$ \\
\hline Salmo trutta trutta & $\mathrm{N}$ & $\mathrm{AN}$ & $\mathrm{CS}$ & $\mathrm{X}$ & $\mathrm{X}$ \\
\hline \multicolumn{6}{|l|}{ Family Scophthalmidae } \\
\hline Scophthalmus rhombus & $\mathrm{N}$ & MS & IF & $\mathrm{X}$ & \\
\hline \multicolumn{6}{|l|}{ Family Sparidae } \\
\hline Diplodus sargus & $\mathrm{N}$ & MS & $\mathrm{OV}$ & $\mathrm{X}$ & \\
\hline \multicolumn{6}{|l|}{ Family Soleidae } \\
\hline Solea solea & $\mathrm{N}$ & MO & $\mathrm{I}$ & $\mathrm{X}$ & \\
\hline \multicolumn{6}{|l|}{ Family Sygnathidae } \\
\hline Nerophis lumbriciformis & $\mathrm{N}$ & MO & IF & $\mathrm{X}$ & \\
\hline Syngnathus abaster & $\mathrm{N}$ & MS & I & $X$ & \\
\hline Syngnathus acus & $\mathrm{N}$ & MO & $\mathrm{IF}$ & $X$ & \\
\hline Syngnathus typhle & $\mathrm{N}$ & MS & IF & $\mathrm{X}$ & \\
\hline \multicolumn{6}{|l|}{ Family Trachinidae } \\
\hline Echiichthys vipera & $\mathrm{N}$ & MS & IF & $\mathrm{X}$ & \\
\hline \multicolumn{6}{|l|}{ Family Triglidae } \\
\hline Chelidonichthys lucerna & $\mathrm{N}$ & MS & IF & $\mathrm{X}$ & \\
\hline
\end{tabular}

Type (N: native; E: endemic; NIS: non-indigenous species), Ecological Guild (modified from Thiel and Potter, 2001; MS: marine stragglers; MO: marine estuarine opportunist; OR: marine opportunistic resident; AN: anadromous; CA: catadromous; ES: estuarine and FW: freshwater fish), Feeding Guild (adapted from Elliott and Dewailly, 1995 and Elliott and Hemingway, 2002) P: feeding on plankton; I: invertebrates; IF: invertebrates and fish; V: plants; D: detritivorous fish; Ps: parasitic fish; CS: carnivorous fish; HC: partly herbivorous, partly carnivorous but not omnivorous and OV: omnivorous fish).

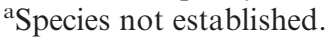

'Species present in the TFWs, but not sampled in this study (authors' unpublished data).

\section{Results}

Water temperature showed a seasonal pattern, with monthly means oscillating between 9.3 and $23.8^{\circ} \mathrm{C}$ and a mean value for the 3 years of sampling at $15.9^{\circ} \mathrm{C}$ (Fig. 3(A)). Rainfall and river flow varied considerably, with peaks between late autumn and spring (Fig. 3(B)). Monthly mean precipitation ranged from 3 to $443 \mathrm{~mm}$, with a mean of $154 \mathrm{~mm}$, and river discharge from 91281 to $1829908 \mathrm{dam}^{3}$, with a mean of $641599 \mathrm{dam}^{3}$.

A total of 13229 fish were collected during the study period, representing 11 families and 21 species (Table 1). Six of these species were NIS, although for the species Lepomis gibbosus (Linnaeus, 1758) just one individual was captured, which is the first report of the species in the Minho estuary. Approximately half of the fish species described in River Minho are also present in the TFWs.

In terms of species contribution for each ecological guild, $82.3 \%$ (61.1\% biomass) were freshwater species, which included all the NIS, $13.2 \%$ were catadromous (30.5\% biomass), $3.6 \%$ were estuarine ( $0.7 \%$ biomass), $0.7 \%$ were anadromous $(5.9 \%$ biomass $)$ and $0.2 \%$ were marine estuarine opportunist ( $1.8 \%$ biomass) (Table 1).

Concerning the feeding guilds, most of the species fed at least on invertebrates (12 species, including three NIS). Additionally, six of those species complemented their diet with plankton or fish (three species each, Table 1).
The mean abundance was usually higher in spring and summer (Fig. 4(A)) and number of species tended to be higher in winter, with a maximum monthly mean value of 12 species in January 2009. The Shannon-Wiener diversity index and Pielou's evenness index were usually higher in autumn although a great variability was observed in the last sampling year (Fig. 5). The most frequently captured species were Cobitis paludica (de Buen, 1930) (34.4\% of the total abundance), Gasterosteus gymnurus (Cuvier, 1829) (15.6\%), Achondrostoma arcasii (Steindachner, 1866) (11.8\%) and Anguilla anguilla (Linnaeus, 1758) $(8.5 \%)$, all native or endemic.

NIS comprised $15.3 \%$ of all fish caught, including Cyprinus carpio (Linnaeus, 1758) and Tinca tinca (Linnaeus, 1758) (4.7\% each), followed by Gobio lozanoi (Doadrio and Madeira, 2004) (3.3\%) and Micropterus salmoides (Lacepède, 1802) (2.5\%). Regarding biomass, T. tinca was the dominant species (35.4\% of total biomass) followed by $A$. anguilla $(24.0 \%), C$. carpio $(8.0 \%)$ and C. paludica $(7.4 \%)$.

Considering the three sampling years separately (each from June to May of the following year) there seems to be a general downward trend in fish abundance and biomass (Table 2). The biomass of the first sampled year (2007/2008) was exceptionally high comparing to the two following years (Fig. 4(B)). The proportion and overall biomass of NIS was relatively stable during the study period, except for $T$. tinca which in the first year was fairly higher than in the other two years (the mean 

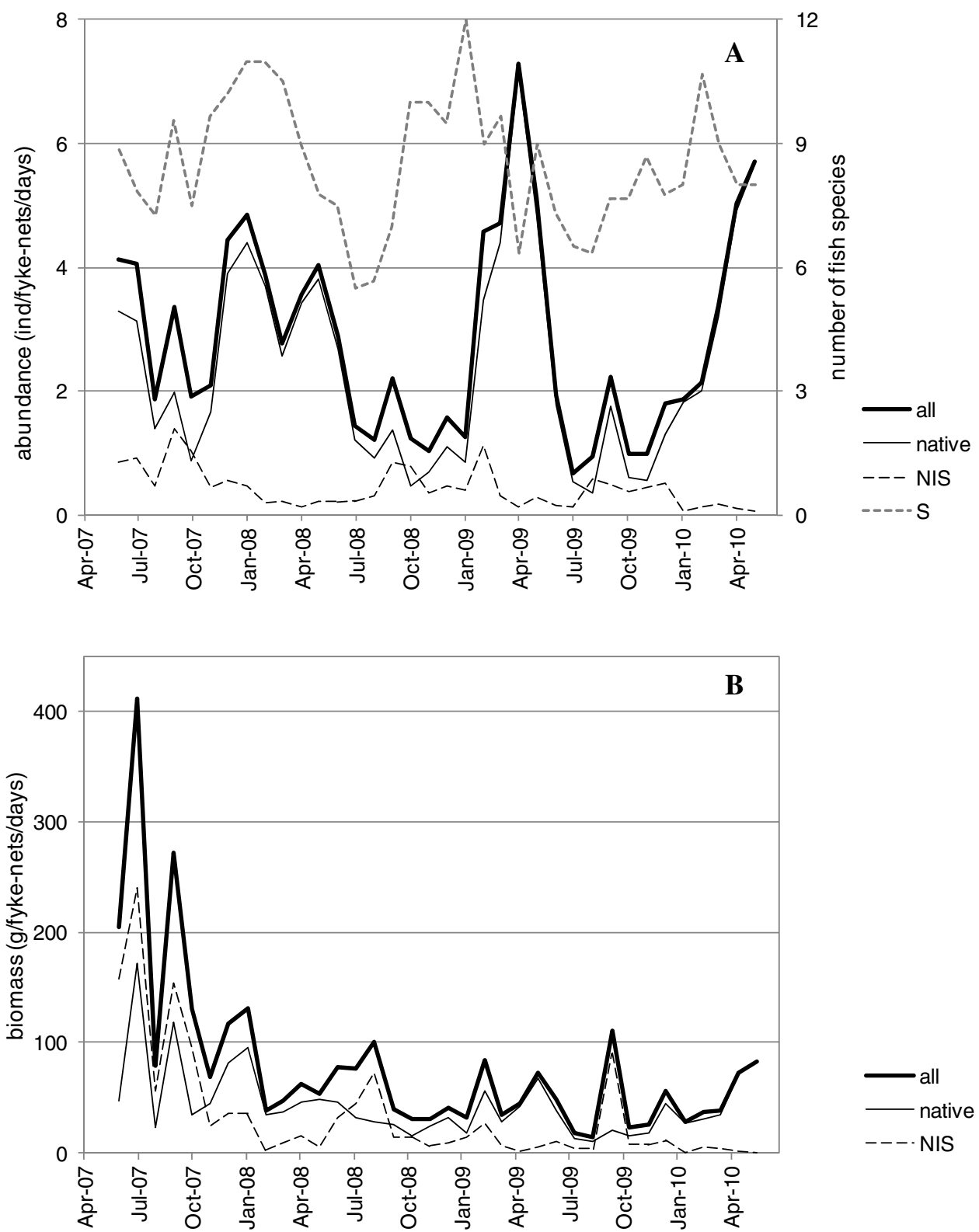

Fig. 4. Monthly mean fish abundance (A) and biomass (B), considering all species (All), native (native) and NIS (NIS) separately, and mean number of species (S) (plot A, right axis).

monthly biomass were $41.7,23.6,17.9 \%$ of the total biomass for each year). The 2007/2008 biomass values were highly influenced by $T$. tinca and $A$. anguilla (the mean monthly biomass were $56.2 \pm 19.5$ and $32.4 \pm 10.5 \mathrm{~g}$ per fyke-net per day mean $\pm \mathrm{SE}$, respectively). In the following year, mean biomass of these species were $13.1 \pm 6.5$ and $12.0 \pm 2.2 \mathrm{~g} /$ fyke-net $\mathrm{d}^{-1}$, and in the third year were $8.3 \pm 7.0$ and $11.8 \pm 2.6 \mathrm{~g}$ per fyke-net per day, respectively.

Cluster analysis based on the Bray-Curtis similarity matrix of abundance revealed four groups (Fig. 6). Group I contains the samples from October 2007 to January 2008; Group II contains samples from October 2008 to January 2009 and from July 2009 to November 2009 (except September 2009); Group III contains samples from the 2007, 2008 and 2009 summers (except July and August 2009) and from the 2010 winter; and Group IV contains samples from the three spring periods. According to the ANOSIM analysis, these groups were distinct (global $R=0.745, P<0.001$; pair-wise tests $0.565 \leq R \leq 0.950,0.001 \leq P \leq 0.003$ ). The species contributing most to the within-group similarities were, for Group I, A. anguilla (contributing 20.8\%), A. arcasii $(19.7 \%)$, G. lozanoi (13.8\%), Atherina boyeri Risso, $1810(10.9 \%)$ and Platichthys flesus (Linnaeus, 1758) (10.8\%); for Group II, C. paludica (22.4\%), C. carpio (20.1\%), A. anguilla (14.3\%) and M. salmoides (13.2\%); for Group III, C. paludica $(52.0 \%)$, A. anguilla $(11.6 \%)$ and C. carpio $(10.1 \%)$; and for Group IV, C. paludica $(46.8 \%)$ and $G$. gymnurus $(31.4 \%)$. Groups were 


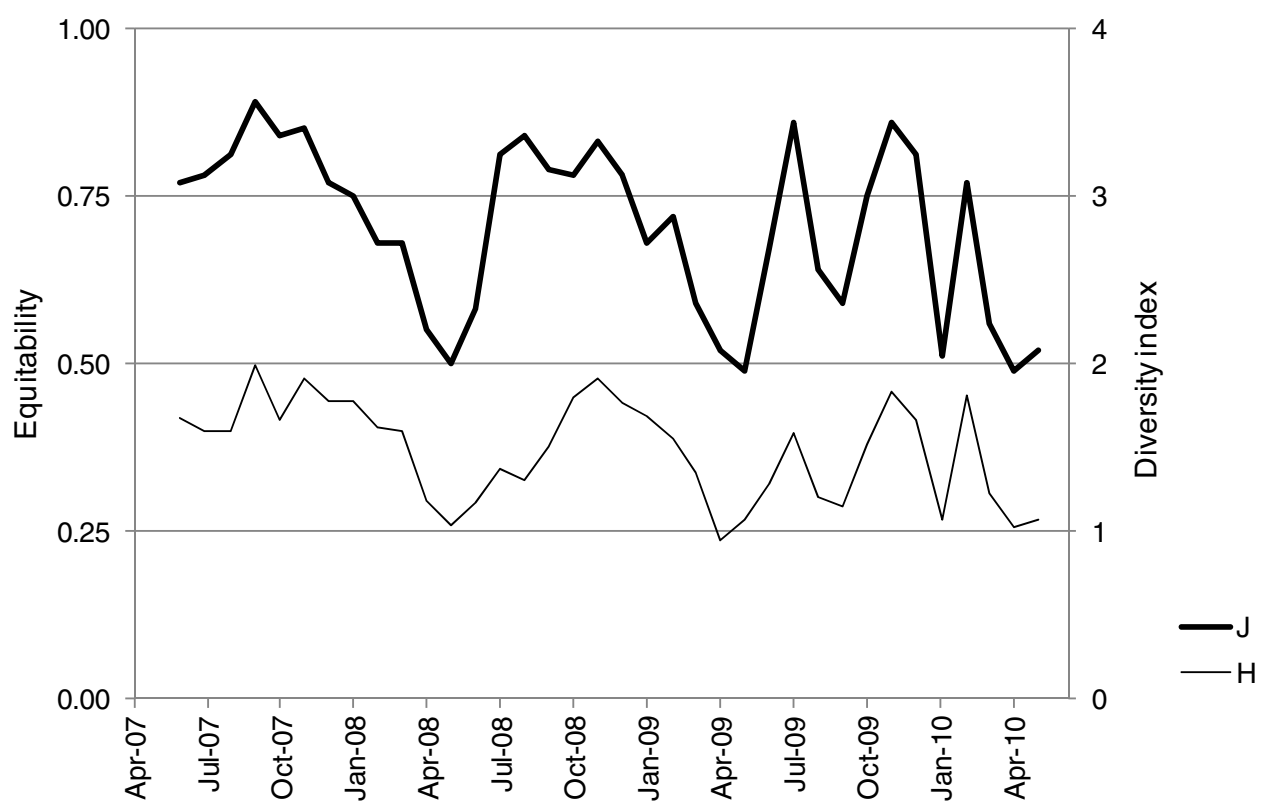

Fig. 5. Equitability (J) and Shannon-Wiener (H) indices of the River Minho TFWs fish assemblage.

Table 2. Inter-annual differences in fish abundance (ind per fyke-net per day) and biomass (g per fyke-net per day), type and ecological guild, equitability, diversity, water temperature, precipitation and river flow.

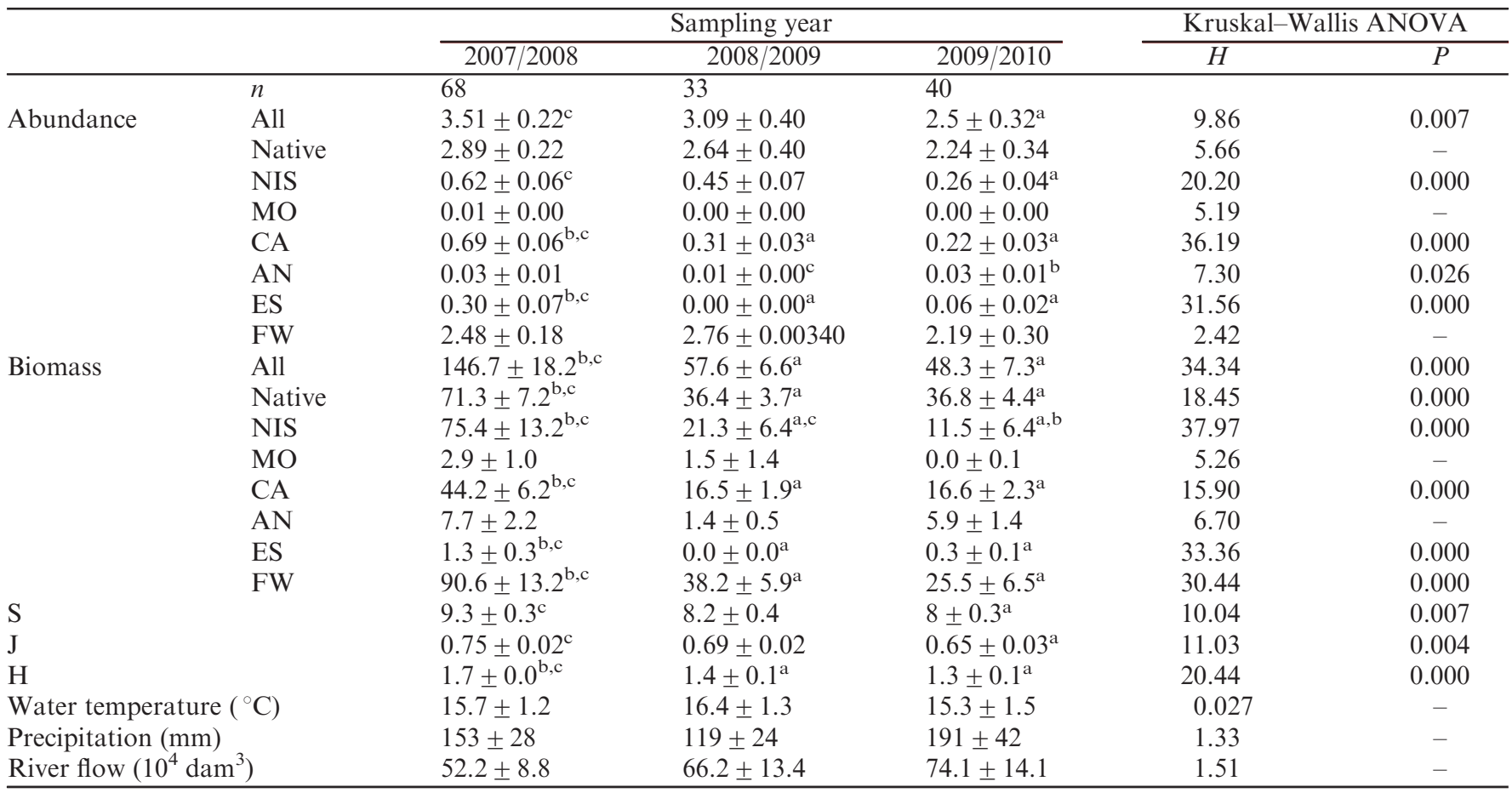

$n$ : number of samples; MO, marine estuarine opportunists; CA, catadromous; AN, anadromous; ES, estuarine; FW, freshwater species; J, Pielou's evenness index; S, number of species; H, Shannon-Wiener diversity index; H, Kruskal-Wallis test value. Mean \pm SE. ${ }^{\mathrm{a}}$, $^{\mathrm{b}}$ and ${ }^{\mathrm{c}}$ indicate the existence of significant differences with 2007/2008, 2008/2009 and 2009/2010 seasons, respectively, for a $P$ value below 0.05 .

characterized by different temperatures and river flow (Fig. 7). Group II (i.e., the second winter, summer and autumn observations) had the lowest fish abundance and biomass; Group I (the first winter) higher biomass and Group IV (spring samples) high abundance and number of species, with higher river flow. Group IV had also clearly less NIS, both in abundance and biomass. 


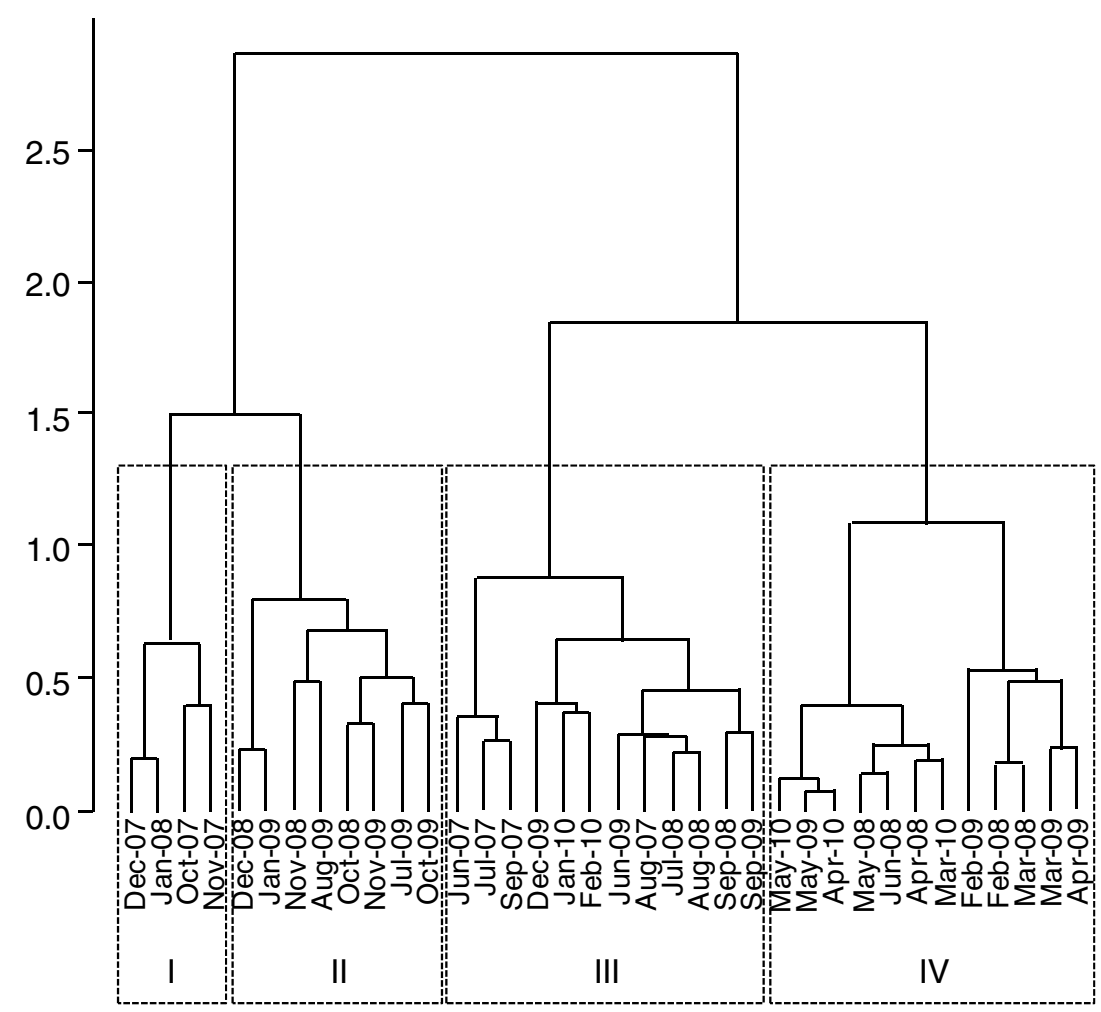

Fig. 6. Bray-Curtis dissimilarity cluster of monthly fish abundance, based on Ward's distances, with the discrimination of four groups.

The fish assemblage of the River Minho TFWs showed a general temporal variability, with a succession of species: $M$. salmoides showing an autumn peak, $A$. arcasii rising in winter (although less abundant in the $3 \mathrm{rd}$ year); G. gymnurus has spring peaks and $C$. paludica presenting a peak in the late spring. Migratory behaviour of eels can justify its activity from October to January, which is represented by higher abundance in this period.

Sample distribution in a two-dimensional NMDS ordination based on fish abundance showed a well separation in groups (Fig. 8(A)); for ease of visualization, fish species are presented in a second plot (Fig. 8(B)). The distribution of species (native and NIS) and biotic indices (Fig. $8(\mathrm{C})$ ) in the fish-species ordination space is also shown as well the ecological guilds and abiotic indices (Fig. 8(D)), summarizing the patterns described above.

Significant linear relationships $(\alpha=0.05)$ was obtained with regression analyses of fish abundance, biomass, fish type and ecological guild, in dependence of temperature, precipitation and river flow. Richness (S) was negatively affected by (high) temperature $(P<0.001)$ and positively affected by precipitation $(P=0.039)$. Temperature had a positive effect on NIS biomass $(P=0.007)$ and on the percentages of NIS abundance $(P=0.038)$ and biomass $(P<0.001)$, whereas river flow had a negative effect on the percentage of NIS biomass $(P=0.036)$. Abundance of anadromous species was negatively affected by temperature $(P=0.027)$ and positively by precipitation
$(P=0.037)$. Temperature had a positive effect on freshwater species abundance $(P=0.031)$ and a negative effect on estuarine species abundance. River flow had a negative effect on the abundance of marine estuarine opportunists $(P=0.042)$.

\section{Discussion}

This study aimed at increasing the knowledge on the ichthyofauna able to colonize River Minho TFWs and the driving abiotic factors responsible for possible temporal changes. The use of fyke nets was effective and temporal (including seasonal and inter-annual) variability in the fish assemblage was evident, despite selectivity for small fish might have occurred. In fact, the number of species captured (total of 21 species) was higher than previous studies using a beam trawl that included the same sampling area (total of 16 species) (França et al., 2011).

\section{Abiotic characterization}

The hydrological annual variability in the River Minho followed other Iberian rivers with a high flow in the autumn/winter period and low flow in the late spring/ summer period (Ferreira et al., 2007). Water temperature followed the same trend, being higher values registered in the summer and lower in the winter. The study was carried out during atypical years regarding precipitation, and 
Temperature $\left({ }^{\circ} \mathrm{C}\right)$

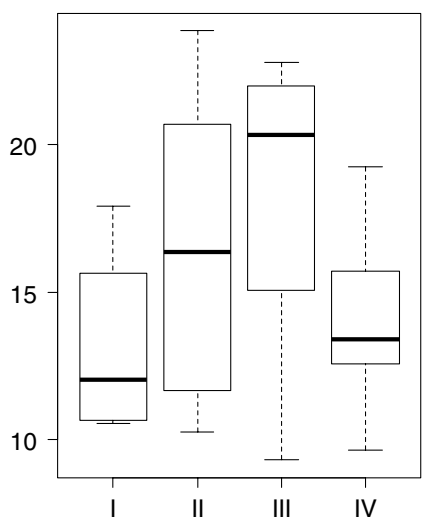

Precipitation ( $\mathrm{mm})$

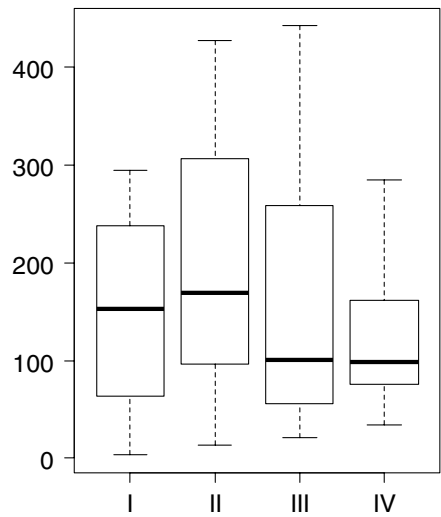

Biomass (g/fyke net/day)
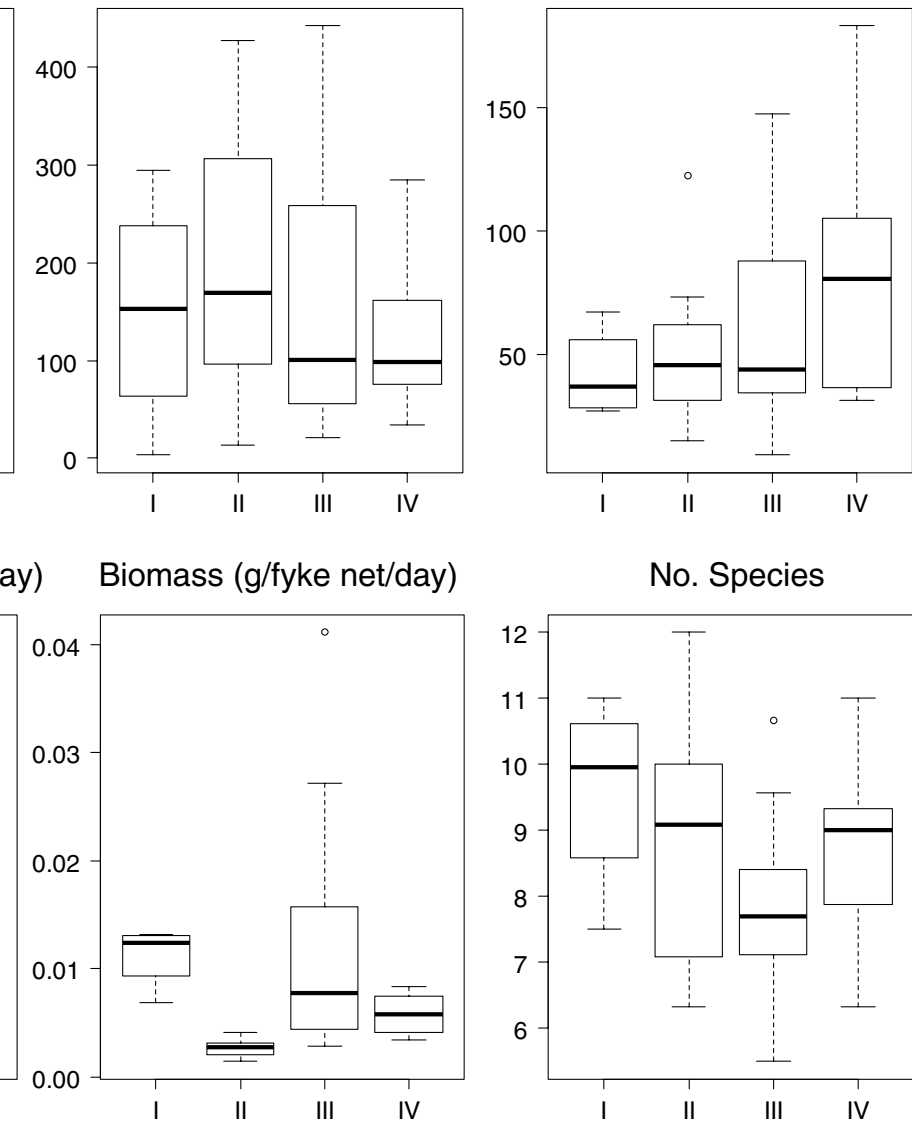

No. Species
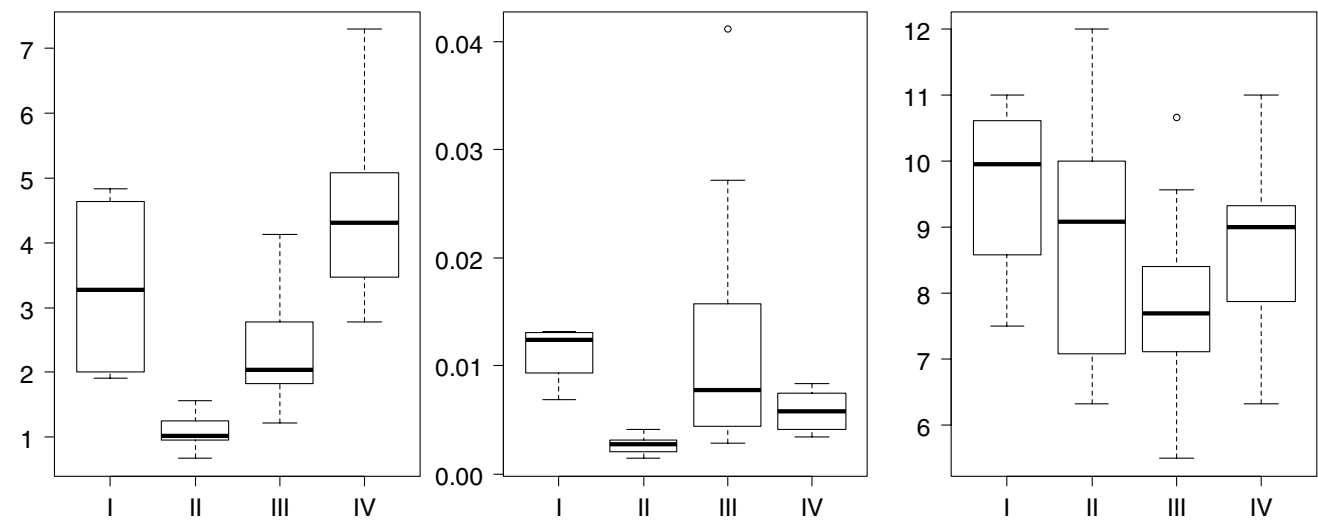

\%NIS Abundance

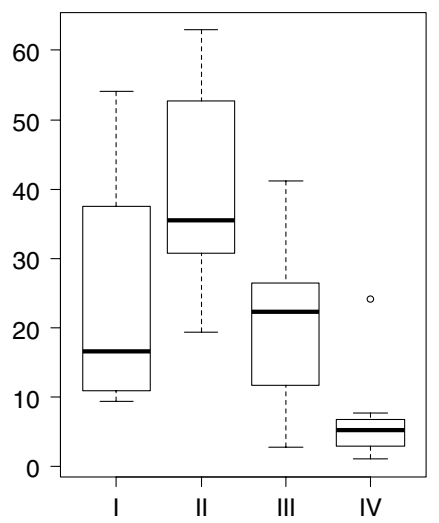

$\%$ NIS Biomass

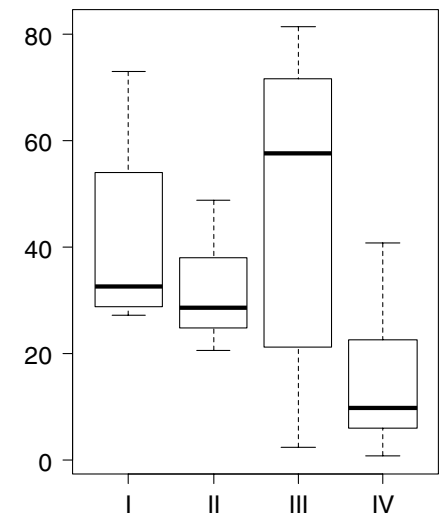

Fig. 7. Monthly data for each of the four groups based on cluster discrimination; boxplots show median values (central line), the range from the first to the third quartile (box), Tuckey whiskers and outliers (dots).

while the first winter was dry, followed by a normal spring, the second winter was wet followed by a dry spring and the third autumn was particularly wet. Differences between precipitation and river flow in autumn 2007, spring 2008 and autumn 2009 were evident, which seems related with dam operations.

The marked seasonal and inter-annual variability of precipitation regime are key factors structuring freshwater fish assemblages in Mediterranean streams (Magalhães et al., 2002) which is also evident in Minho TFWs (this work). For example, higher water temperatures had a significant negative effect on the observed number of species, but a positive effect on the abundance and biomass of NIS. Although this study just comprises a 3 years, it seems that water temperature increase will benefit the presence of NIS. 

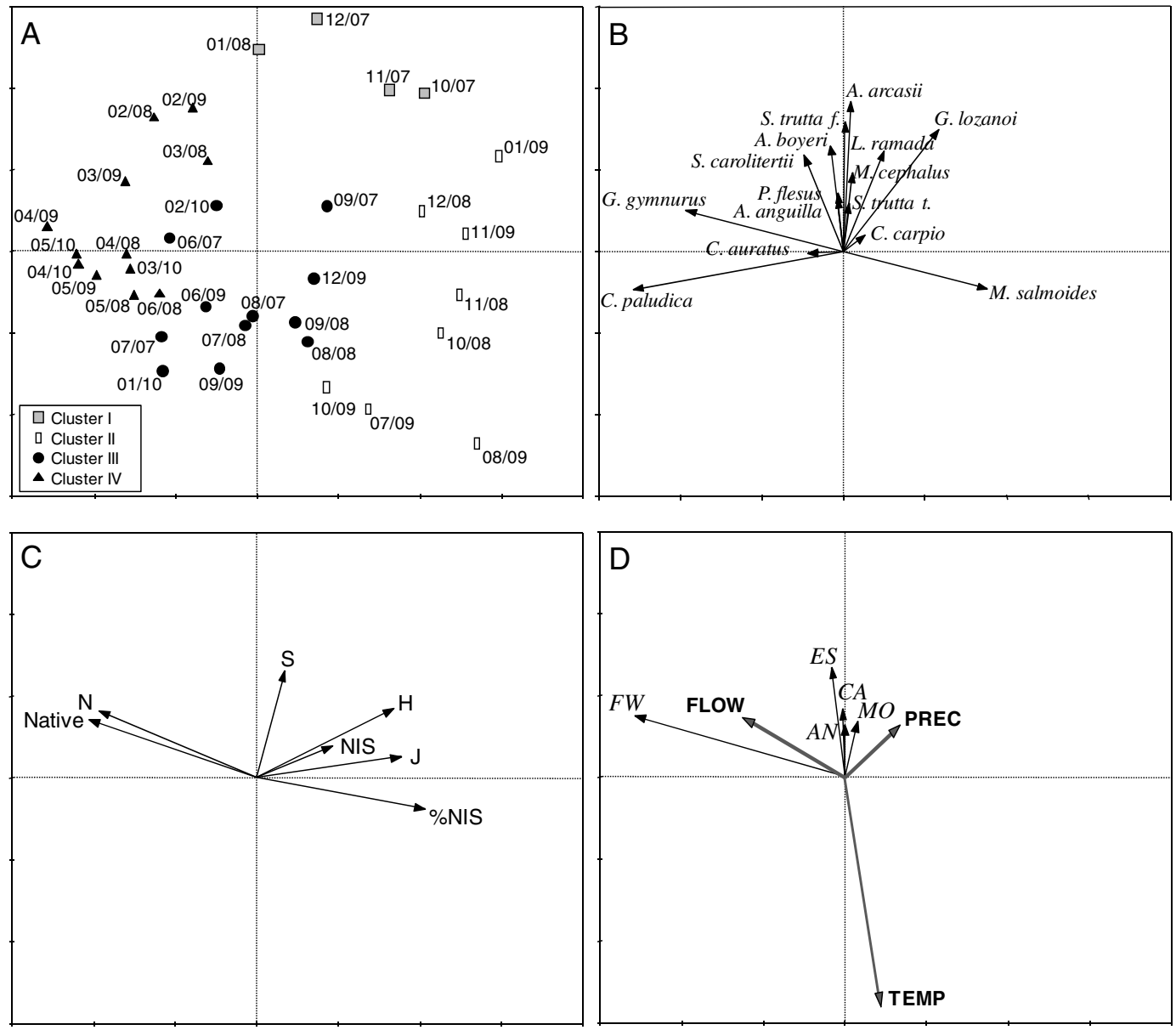

Fig. 8. NMDS ordination of the monthly fish abundance samples with: (A) distribution of the samples marked according to the identified groups; (B) distribution of the fish species (species occurring in less than 4 months and species with very little effect in the ordination were omitted in the plot); (C) distribution native fish and NIS abundance, percentage NIS, evenness and diversity indices in the ordination space; (D) distribution of ecological guilds (MO, marine estuarine opportunists; ES, estuarine; CA, catadromous; AN, anadromous and FW, freshwater species), water temperature (TEMP), precipitation (PREC) and river flow (FLOW) in the ordination space.

\section{Biotic characterization}

Forty-three per cent of the total number of fish species described previously in the Minho estuary (49 according with Antunes and Rodrigues, 2004 and Costa-Dias et al., 2010) were captured in the TFWs. A strong dominance of freshwater species and the occurrence of four of the five endemic species and six of the seven non-indigenous fish species previously described in all drainage basin were recorded. Cyprinidae and Cobitidae were the most common families and followed other studies performed in several Iberian streams (e.g., Hernando and Soriguer, 1992; Encina et al., 2006).

Three species appeared recently in the River Minho and their presence should be discussed following their ecological significance: the Southern Iberian spined-loach (C. paludica), the Pyrenean gudgeon (G. lozanoi) and the Pumpkinseed sunfish (L. gibbosus). The Southern Iberian spined-loach (C. paludica) inhabits several rivers in Central and Southern Iberian and is considered an endemism of IP (Doadrio et al., 2011). However, the presence of this species in the River Minho basin has been recently described for the first time; in the tributary River Tea by Xunta de Galicia (1996) and in a small pond in a Minho TFW area by Cigoña and Ferreira (1996). This species remained restricted to a small area in the following years until the floods of $2000 / 2001$, when its distribution range increased considerably, and currently it covers River Minho TFWs. Owing to the Iberian status of this species, we have assumed it like a IP translocated endemic species from nearby catchment areas, in agreement with Doadrio (2002). Recent consensus suggests that Adour (France) and Bidasoa (Spain) drainages constitute the native area of $G$. lozanoi and this species is known to have been introduced in many Iberian drainage basins since 19th century mediated by human activities (Leunda et al., 2009). The genus Gobio was only firstly described in the 1990s for River Minho TFWs (Antunes and Rodrigues, 2004) and in different tributaries of the River Minho in Galicia (Xunta de Galicia, 2007), thus, we assumed 
this species as NIS in this river in the present study. Lepomis gibbosus was also captured and described for the first time in this study area. Although this species is not established in the River Minho main channel, according to information provided by Xunta de Galicia this NIS is already established in the Minho tributaries Avia and Loña (Cachamuiña and Castadón dams, respectively).

In the River Minho TFWs, six ecological guilds were present (within a total of seven described for the whole estuary) including freshwater fish which were the highest in number, followed by catadromous, estuarine, anadromous and marine estuarine opportunist fish. Data from May and July 2006, covering the entire River Minho estuarine gradient, showed higher proportion of marine seasonal migrants (França et al., 2011). Owing to its high salinity dependence, this group was not present in our study and such differences show the importance to cover all estuarine area when the aim is to study the variability of the intra-estuarine fish assemblages assess. The absence of marine estuarine opportunist species in TFWs is highly dependent of river flow which in turn positively affects the anadromous fish species.

Invertebrates are crucially important for wetlands because of their central position in food webs (Batzer et al., 1999) and most of the ichthyofauna captured in the River Minho TFW fed on those species. Additionally, carnivorous species (one NIS, two migratory and one native freshwater species) were also captured. In this sense, $M$. salmoides is one of the oldest introductions in the River Minho and before the 1990s colonized the same habitat of Squalius carolitertii (Doadrio, 1988) in the study area, belonging both to the same feeding guild. After introduction of omnivorous cyprinids both species abundance decreased and even $S$. carolitertii has almost disappeared from this area (Antunes, personal observation).

Overall, the most important differences between the fish assemblage of the whole Minho estuary and the typical European estuarine fish assemblage (Elliott and Dewailly, 1995) are a smaller number of estuarine resident species, a greater percentage of freshwater species and a smaller proportion of benthic species (Table 1).

\section{Ecological significance}

Aquatic ecosystems have been subjected to numerous threats such as loss and/or fragmentation of habitats, pollution, channelization, overexploitation of resources and introduction of NIS (Mota et al., 2014). In the River Minho TFWs particularly important are the impacts imposed by the construction of dams in upstream areas and the introduction of several NIS (Sousa et al., 2008a). The dams control the river flow in a non-natural way and this situation may influence the fish assemblage. Although non-indigenous fish species do not reach dramatic numbers in River Minho as in several Iberian rivers (Elvira and Almodóvar, 2001), they are still matters of concern. Most of these species were recently introduced, and in the
River Minho TFWs, three new NIS are described in this study when comparing with earlier data (Antunes, 1990; Antunes and Weber, 1990), namely C. carpio, and T. tinca, in addition to one specimen of $L$. gibbosus. The number of established non-indigenous fish species in IP ranges between 28 and 38 (Cobo et al., 2010; Leunda, 2010; Doadrio et al., 2011). Cobo et al. (2010) found delays for introduction in Galicia (further NW region of IP) up to 100 years for species introduced in the IP at the beginning of the 20th century. However, species introduced in the IP after 1995 are almost immediately present in Galicia. The Minho drainage basin is almost exclusively located in this region which explains that $80 \%$ of the NIS present in Galicia are also present in the River Minho. Moreover, it will be highly likely that the Minho drainage basin will face additional introductions in the future.

The native freshwater fish fauna of IP is characterized by a low number of families with a great predominance of species belonging to the Cyprinidae family. However, due to its isolation, orographic and climatic peculiarities, IP is well known for its high degree of biodiversity at the species level and has the greatest European percentage of endemic freshwater fish fauna (Hernando and Soriguer, 1992; Encina et al., 2006). Our study supports these findings and several fish species described in this study are also considered endemic for the IP (e.g., A. arcasii, Pseudochondrostoma duriense (Coelho, 1985), S. carolitertii and C. paludica).

\section{Conclusion}

The results clearly show a temporal dynamics in the fish assemblage present in the River Minho TFWs. The information gathered in this study is very important and therefore, TFWs should also be considered in future management plans concerning the River Minho estuary. More attention has to be given to TFWs and their role structuring fish assemblages because this information may be vital for conservation and restoration of estuarine areas. Indeed, the understanding of the relationships between fish assemblages and environmental variations is of particular relevance for conserving the Iberian ichthyofauna biodiversity, which includes a high number of endemisms.

Acknowledgements. The authors would like to thank Rodrigo Lopez for the study area map arrangement and Eduardo Martins for the field work assistance. This research was partially supported by the European Regional Development Fund (ERDF) through the COMPETE - Operational Competitiveness Programme and national funds through FCT - Foundation for Science and Technology, under the project PEst-/MAR/LA0015/2013.

\section{References}

Antunes C., 1990. Abundância, distribuição sazonal e diversidade da fauna ictiológica do estuário do rio Minho 
("Abundance, seasonal distribution and diversity of ichthyofauna in River Minho estuary" in Portuguese), Instituto Ciências Biomédicas Abel Salazar, University of Porto, Portugal, 90 p.

Antunes C. and Rodrigues H., 2004. Guia natural do Rio Minho - Os Peixes ("Natural guide of River Minho - fish", in Portuguese), Aquamuseu do Rio Minho. Câmara Municipal de Vila Nova de Cerveira. Vila Nova de Cerveira, Portugal, $84 \mathrm{p}$.

Antunes J.C. and Weber M., 1990. A pesca profissional no estuário do rio Minho-resultados da pesca experimental ("The professional fisheries in River Minho estuary experimental fisheries results" in Portuguese). Proceedings of the 1st Symposium on Protection and Revaluation of Minho - Liz section, 16-31.

Attrill M.J., 2002. A testable linear model for diversity trends in estuaries. J Anim. Ecol., 71, 262-269.

Attrill M.J. and Rundle S.D., 2002. Ecotone or ecocline: ecological boundaries in estuaries. Estuar. Coast. Shelf $S$., 55, 929-936.

Barendregt A., Whigham D. and Baldwin A. (eds.), 2009. Tidal Freshwater Wetlands, Backhuys Publishers, Leiden, 320 p.

Batzer D.P., Radar R.B. and Wissinger S.A., 1999. Invertebrates in Freshwater Wetlands of North America: Ecology and Management, John Wiley \& Sons, USA.

Becker R.A., Chambers J.M. and Wilks A.R., 1988. The New S Language. Wadsworth \& Brooks/Cole (S version), Pacific Grove, CA, USA.

Buisson L., Blanc L. and Grenouillet G., 2008. Modelling stream fish species distribution in a river network: the relative effects of temperature versus physical factors. Ecol. Freshw. Fish, 17, 244-257.

Cigoña E.F. and Ferreira S.G., 1996. Peces desconocidos da Galicia, la lamprehuela ibérica Cobitis calderoni en las aguas del bajo Miño ("Unknown fish of Gallician, Iberian loach Cobitis calderoni in Miño estuary waters" in Spanish). Proceedings of the 1st Iberian Symposium of River Minho Hydrological Basin, Portugal, 65-71.

Clarke K.R. and Warwick R.M., 2001. Change in Marine Communities: an Approach to Statistical Analysis and Interpretation (2nd edn), PRIMER-E Ltd, Plymouth Marine Laboratory, Plymouth.

Cobo F., Vieira-Laneiro R. and Servia M.J., 2010. Temporal trends in non-indigenous freshwater species records during the 20th century: a case study in the Iberian Peninsula. Biodivers. Conserv., 19, 3471-3487.

Costa-Dias S., Freitas V., Sousa R. and Antunes C., 2010. Factors influencing epibenthic assemblages in the Minho estuary (NW Iberian Peninsula). Mar. Pollut. Bull., 61, 240-246.

Doadrio I., 2002. Atlas y Libro Rojo de los Peces Continentales de España ("Atlas and Red Book of Continental fish of Spain" in Spanish). Dirección General de Conservación de la Naturaleza/Museo Nacional de Ciencias Naturales-CSIC, Madrid, 364 p.

Doadrio I., Perea S., Garzón-Heydt P., González J.L., 2011. Ictiofauna Continental Española ("Spanish Continental Ichthyofauna" in Spanish), DG Medio Natural y Política Foresta. MARM, Madrid. ISBN:978-84-491-1158-7.

Elliott M. and Dewailly F., 1995. The structure and components of European estuarine fish assemblages. Neth. J. Aquat. Ecol., 29, 397-417.
Elliott M. and Hemingway K.L. (eds.), 2002. Fishes in Estuaries, Blackwell Science, Oxford, 636 p.

Elvira B. and Almodóvar A., 2001. Freshwater fish introductions in Spain: facts and figures at the beginning of the $21 \mathrm{st}$ century. J. Fish Biol., 59, 323-331.

Encina L., Rodríguez A. and Granado-Lorencio C., 2006. The Iberian ichthyofauna: ecological contributions. Limnetica, 25(1-2), 349-368.

Ferreira J.G., Simas T., Nobre A., Silva M.C., Shifferegger K. and Lencart-Silva J., 2003. Identification of sensitive areas and vulnerable zones in transitional and coastal Portuguese systems. Application of the United States National Estuarine Eutrophication Assessment to the Minho, Lima, Douro, Ria de Aveiro, Mondego, Tagus, Sado, Mira, Ria Formosa and Guadiana systems. INAG/IMAR ISBN 972-9412-66-9.

Ferreira M.T., Sousa L., Santos J.M., Reino L., Oliveira J., Almeida P.R. and Cortes R.V., 2007. Regional and local environmental correlates of native Iberian fish fauna. Ecol. Freshwat. Fish, 16, 504-514.

Field J.G., Clarke K.R. and Warwick R.M., 1982. A practical strategy for analysing multispecies distribution patterns. Mar. Ecol. Prog. Ser., 8, 37-52.

França S., Costa M.J. and Cabral H.N., 2011. Inter- and intraestuarine fish assemblage variability patterns along the Portuguese coast. Estuar. Coast. Shelf S., 91, 262-271.

Hernando J.A. and Soriguer M.C., 1992. Biogeography of the freshwater fish of the Iberian Peninsula. Limnetica, 8, 243-253.

Humphries P., Brown P., Douglas J., Pickworth A., Strongman R., Hall K. and Serafini L., 2008. Flow-related patterns in abundance and composition of the fish fauna of a degraded Australian lowland river. Freshwat. Biol., 53, 789-813.

Kappel C., 2005. Losing pieces of the puzzle: threats to marine, estuarine, and diadromous species. Front. Ecol. Environ., 3, 275-282.

Kraus R.T. and Jones R.C., 2012. Fish abundances in shoreline habitats and submerged aquatic vegetation in a tidal freshwater embayment of the Potomac River. Environ. Monit. Assess., 184(5), 3341-3357.

Leunda P.M., 2010. Impacts of non-native fishes on Iberian freshwater ichthyofauna: current knowledge and gaps. Aquat. Invasions, 5(3), 239-262.

Leunda P.M., Elvira B., Ribeiro F., Miranda R., Oscoz J., Alves M.J., Collares-Pereira M.J., 2009. International standardization of common names for Iberian endemic freshwater fishes. Limnetica, 28, 189-202.

Little C., 2000. The Biology of Soft Shores and Estuaries, Oxford University Press, New York.

Lotze H., Lenihan H., Bourque B., Bradbury R., Cooke R., Kay M., Kidwell S., Kirby M., Peterson C. and Jackson J., 2006. Depletion, degradation, and recovery potential of estuaries and coastal seas. Science, 312, 1806-1809.

Magalhães M.F., Batalha D.C. and Collares-Pereira M.J., 2002. Gradients in stream fish assemblages across a Mediterranean landscape: contributions of environmental factors and spatial structure. Freshwat. Biol., 47, 1015-1031.

Mota M., Sousa R., Araújo J., Braga C. and Antunes C., 2014. Ecology and conservation of freshwater fish: time to act for a more effective management. Ecol. Freshwat. Fish, 23, $111-113$. 
Oksanen J., Blanchet F.G., Kindt R., Legendre P., O'Hara R.B., Simpson G.L., Solymos P., Stevens M.H. and Wagner H., 2010. Community Ecology Package. R package version 1, 17-4. WWW Page, http://CRAN.R-project.org/ package $=$ vegan .

R Development Core Team, 2009. R: A Language and Environment for Statistical Computing, R Foundation for Statistical Computing, Vienna, Austria, WWW Page, http:// www.R-project.org.

Roegner G.C., Dawley E.W., Russell M., Whiting A. and Teel D.J., 2010. Juvenile salmonid use of reconnected tidal freshwater wetlands in Grays River, lower Columbia River basin. Trans. Am. Fish. Soc., 139, 1211-1232.

Schuchardt B., Haesloop U. and Schirmer M., 1993. The tidal freshwater reach of the Weser estuary: riverine or estuarine? Neth. J. Aquat. Ecol., 27, 215-226.

Sousa R., Dias S., Guilhermino L. and Antunes C., 2008a. Minho River tidal freshwater wetlands: threats to faunal biodiversity. Aquat. Biol., 3, 237-250.

Sousa R., Dias S., Freitas V. and Antunes C., 2008b. Subtidal macrozoobenthic assemblages along the River Minho estuarine gradient (north-west Iberian Peninsula). Aquat. Conserv., 18, 1063-1077.
Sousa R., Freitas F., Nogueira A.J.A., Mota M. and Antunes C., 2013. Invasive dynamics of the crayfish Procambarus clarkii (Girard, 1852) at the international section of the River Minho (NW of the Iberian Peninsula). Aquat. Conserv., 23, 656-666.

Thiel R. and Potter I.C., 2001. The ichthyofaunal composition of the Elbe estuary: an analysis in space and time. Mar. Biol., 138, 603-616.

Vasconcelos R.P., Reis-Santos P., Fonseca V., Maia A., Ruano M., França S., Vinagre C., Costa M.J. and Cabral H., 2007. Assessing anthropogenic pressures on estuarine fish nurseries along the Portuguese coast: a multi-metric index and conceptual approach. Sci. Total Environ., 374, 199-215.

Ward J.H., 1963. Hierarchical grouping to optimize an objective function. J. Am. Stat. Assoc., 58, 236-244.

Xunta de Galicia, 1996. Inventario piscícola-1995: cuencas de los rios Mandeo, Eo, Arnoia, Tea, Lérez y Ulla ("Fish inventory - 1995: drainages of Rivers Mandeo, Eo, Arnoia, Tea, Lérez and Ulla" in Spanish). Centro de Investigacions Forestais, Lourizan, Pontevedra, 107 p.

Xunta de Galicia, 2007. Plan de ordenacion dos recursos piscícolas ("Management plan of fish resources" in Spanish). Conselleria de Medio Ambiente e Desenvolvemento Sostible, Santiago de Compostela. 